\title{
Interactions between histaminergic and cholinergic systems in learning and memory
}

\author{
Lucia Bacciottini, Maria Beatrice Passani, Pier Francesco Mannaioni, \\ Patrizio Blandina* \\ Dipartimento di Farmacologia Preclinica e Clinica, Universitá di Firenze, Viale G. Pieraccini 6, 50139 Firenze, Italy
}

Received 22 September 1999; accepted 27 June 2000

\begin{abstract}
The aim of this review is to survey biochemical, electrophysiological and behavioral evidence of the interactions between the cholinergic and histaminergic systems and evaluate their possible involvement in cognitive processes. The cholinergic system has long been implicated in cognition, and there is a plethora of data showing that cholinergic deficits parallel cognitive impairments in animal models and those accompanying neurodegenerative diseases or normal aging in humans. Several other neurotransmitters, though, are clearly implicated in cognitive processes and interact with the cholinergic system. The neuromodulatory effect that histamine exerts on acetylcholine release is complex and multifarious. There is clear evidence indicating that histamine controls the release of central acetylcholine ( $\mathrm{ACh}$ ) locally in the cortex and amygdala, and activating cholinergic neurones in the nucleus basalis magnocellularis (NBM) and the medial septal area-diagonal band that project to the cortex and to the hippocampus, respectively. Extensive experimental evidence supports the involvement of histamine in learning and memory and the procognitive effects of $\mathrm{H}_{3}$ receptor antagonists. However, any attempt to strictly correlate cholinergic/histaminergic interactions with behavioral outcomes without taking into account the contribution of other neurotransmitter systems is illegitimate. Our understanding of the role of histamine in learning and memory is still at its dawn, but progresses are being made to the point of suggesting potential treatment strategies that may produce beneficial effects on neurodegenerative disorders associated with impaired cholinergic function. (C) 2001 Elsevier Science B.V. All rights reserved.
\end{abstract}

Keywords: Acetylcholine; Histamine; Amygdala; Hippocampus; Cerebral cortex; Release

\section{Introduction}

The extensive loss of cholinergic neurons in the basal forebrain, detected at autopsy [104] and, more recently, using chemical imaging [73], is the most salient neurochemical feature of Alzheimer's disease [27], and has been linked to cognitive impairment [105]. Furthermore, both cholinergic [32] and memory deficits [72] occur also in normal aging, although these dysfunctions differ qualitatively and quantitatively from those reported in AD. These observations, together with a

\footnotetext{
* Corresponding author. Tel.: + 39-055-4271239; fax: + 39-0554271280.

E-mail address: blandina@server1.pharm.unifi.it (P. Blandina).
}

wealth of data showing that anticholinergic drugs, such as scopolamine and atropine, produced learning and memory deficits $[25,35,44]$, have led to the cholinergic hypothesis of geriatric cognitive dysfunction [10]. As a result, much of the research on cognitive decline has focused on the role of central acetylcholine (ACh) [41], and related treatment strategies have traditionally aimed at restoring the cholinergic neurotransmission. However, therapies with cholinesterase inhibitors or muscarinic agonists have been generally unproductive [69], being improvements of cognitive functions generally modest and confined to a minority of patients, although whether such therapies provide protection against further cognitive decline is still being evaluated [103]. These drugs may disrupt the normal pattern of cholinergic transmission, thus blocking proper signal 
processing. In addition, over the past decade much evidence has shown that the 'cholinergic hypothesis of learning' [10] is too reductionistic. [58,112]. Different pathological manifestations of $\mathrm{AD}$, such as $\beta$-amyloidosis, presence of tangles and dystrophic neurites, synapse loss and various neurotransmitters deficits render unlikely that cholinergic dysfunction could account for all cognitive and non-cognitive symptoms. Furthermore, several neurotransmitters, including dopamine, GABA, noradrenaline, serotonin and histamine, are clearly implicated in cognitive processes and interact with the cholinergic system $[33,99]$. Since abnormalities of these neurotransmitter systems have been identified in Alzheimer's disease and aging [1,57], these alterations might well interact with those of ACh to cause additive or even synergistic effects on cognition. For instance, the role of serotonin in learning and memory has received much interest [76], although the data appear to be rather inconsistent [76]. Nevertheless, $5 \mathrm{HT}_{3}$ antagonists seemed to improve the performance of rodents and primate in various cognitive tests [102], possibly through modulation of cholinergic mechanisms [52]. Also dopamine, especially the mesocortical system, is thought to have a crucial role in learning and memory [74]. Increased dopamine turnover in the prefontal cortex impaired spatial memory performance [88]. In the auditory cortex an increase of dopaminergic activity evaluated by microdialysis appeared to reflect the initial formation of the behaviorally relevant association [120], and the phasic activation of mesocortical and mesolimbic dopaminergic systems is differentially influenced by associative and non associative learning mechanisms [11]. Histamine implications in learning and memory is supported by extensive experimental evidence $[94,124]$, and there is evidence that histaminergic $\mathrm{H}_{3}$ receptor antagonists facilitated memory acquisition [51], possibly through cholinergic mechanisms [99]. Interestingly the effect of tacrine (1,2,3,4-tetrahydroamino-9-acridinamine), which alleviates Alzheimer's disease symptoms in some patients, may be partly due to multiple pharmacological mechanisms. Although protection of endogenous $\mathrm{ACh}$ is its most accepted mechanism of action, through acetylcholinesterase inhibition, tacrine was more potent to inhibit histamine- $N$-methyltransferase, the enzyme responsible for brain histamine metabolism, than acetylcholinesterase [86]. The enhancement of histamine brain level might be related with the activity of tacrine in Alzheimer's disease. Thus, the role of interactions between $\mathrm{ACh}$ and other neurotransmitters affecting cognition is of considerable interest. This review focuses on interactions between the cholinergic and the histaminergic systems and examines the possible role of such interactions in learning and memory.

\section{Modulation of hippocampal cholinergic tone by histamine}

The cholinergic system might be one of the most important modulatory neurotransmitter systems in the brain. It is distributed in a variety of different nuclei, two groups of which are localized in the forebrain. The nucleus basalis magnocellularis (NBM) is the major source of cholinergic innervation to the neocortex, and the amygdala, whereas the medium septum-banda diagonalis complex (MSA-DB) provides cholinergic input to the hippocampus $[78,89,135]$. Since degeneration of these two cholinergic pathways is the most consistent damage occurring in Alzheimer's disease [27], a large number of studies have investigated the regulation of either NBM or MSA-DB cholinergic neurons. These neurons appear to be interconnected with several neurotransmitters, such as dopamine, noradrenaline, serotonin, GABA, opioids, galanin, substance $\mathrm{P}$ and angiotensin II [33]. There is also much evidence suggesting that histaminergic system modulates both NBM and MSA-DB cholinergic pathways [13,100]. Indeed, histaminergic cell bodies are exclusively localized in the tuberomammillary nucleus of the hypothalamus [97,131], from where they project efferent fibers, pre-

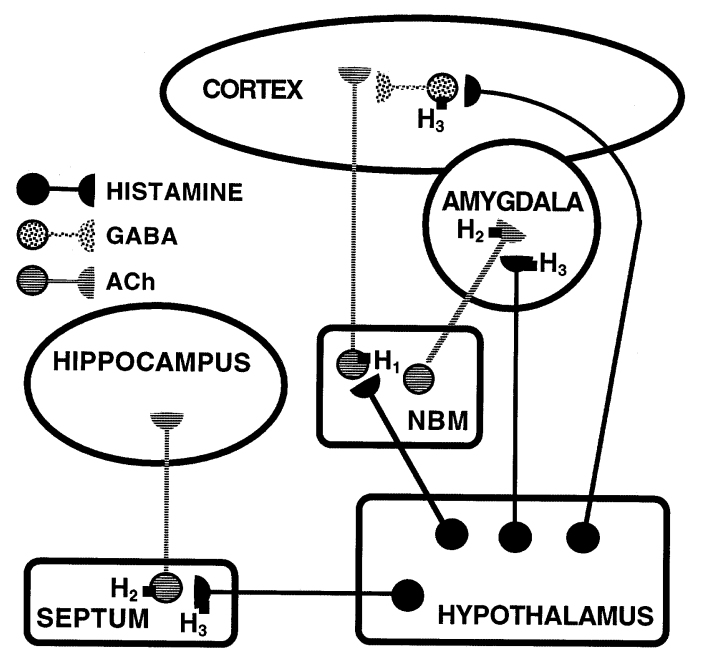

Fig. 1. Schematic diagram of the sites at which cholinergic/histaminergic interactions might occur. Three systems may be of special interest, the nucleus basalis magnocellularis (NBM)/cortical system, the NBM/amygdaloid system and the medium septum-banda diagonalis (MSA-DB)/hippocampal system. Drugs acting at $\mathrm{H}_{1}$ receptors may affect cortical cholinergic tone by interacting with cholinergic perikarya in the NBM, whether directly or indirectly is not known yet. $\mathrm{H}_{2}$ receptor agonists or antagonists may affect the cholinergic tone in the amygdala at cholinergic terminals level. They may also modulate the hippocampal cholinergic tone by interacting with cholinergic perikarya in the MSA-DB, whether directly or indirectly is not known yet which. $\mathrm{H}_{3}$ receptor ligands may interact with autoreceptors in the septum and the amygdala, thus modulating indirectly the cholinergic tone in the amygdala and the hippocampus. They may also thus affect cortical cholinergic activity by acting at postsynaptic $\mathrm{H}_{3}$ receptors localized on GABAergic neurons. 
dominantly ipsilaterally and with multifold arborizations, into the whole central nervous system, including the NBM, MSA-DB, amygdala, hippocampus and cerebral cortex [64,96,123,130]. Fig. 1 shows a schematic diagram of the sites at which cholinergic/histaminergic interactions might occur.

Hippocampus has long been thought to be an important cortical region for associative learning and memory. An early study indicated that ACh release from the CA1-CA3 region of hippocampus of anesthetized rats could be modulated by endogenous histamine [83]. Indeed, an electrical stimulation applied to the tuberomammillary nucleus greatly increased both histamine release from MSA-DB and ACh release from hippocampus. Similar results were obtained when the hypothalamus was perfused with a $100 \mathrm{mM}$ potassiumcontaining medium [83]. ACh release was increased through the release of histamine, since both ACh and histamine electrically-evoked releases were abolished in rats pretreated with $\alpha$-fluoromethylhistidine, a suicide inhibitor of histidine decarboxylase. This enzyme is essential for histamine synthesis [71], and its blockade caused a complete depletion of neuronal histamine [132]. ACh electrically-elicited release was inhibited by systemic administration of zolantidine, an $\mathrm{H}_{2}$ receptor antagonist [21], but not of pyrilamine, an $\mathrm{H}_{1}$ receptor antagonist, thus indicating that activation of $\mathrm{H}_{2}$ receptors resulted in an increase of extracellular level of hippocampal ACh [83]. Stimulation of $\mathrm{H}_{2}$ receptors released also endogenous noradrenaline from rat hypothalamic slices [16] and prolactin [34]. The implication of endogenous histamine was further supported by the observation that administration of thioperamide, an $\mathrm{H}_{3}$ receptor antagonist [4], increased, while that of $\mathrm{R}-\alpha-$ methylhistamine, an $\mathrm{H}_{3}$ receptor agonist [4], decreased ACh spontaneous release from hippocampus [83]. Indeed, the $\mathrm{H}_{3}$ receptor was initially discovered on histaminergic neurons as a presynaptic autoreceptor, whose activation inhibited the release of histamine, and its blockade elicited an increase of histamine extracellular levels $[4,5]$.

Electrical stimulation of tuberomammillary nucleus enhanced histamine release not only from MSA-DB, but also from hippocampus, thus indicating that it might act at both the cell bodies and the terminals of the cholinergic system [83]. However, since the electrical stimulation elicited a response in histamine release from MSA-DB six-fold greater than that elicited from hippocampus, it is perhaps more likely that an interaction between histaminergic and cholinergic systems occurred in the MSA-DB complex. These observations have been largely confirmed and extended, and it is clear yet that histamine exerts a tonic influence on hippocampal cholinergic activity only at MSA-DBcomplex level. In fact, microdialysis experiments have failed to show an effect of histamine, applied locally to hippocampus, on extracellular level of hippocampal ACh [8]. In the extension of this study, histamine receptor-selective compounds were applied by retrograde microdialysis to the MSA-DB area of the rat brain, and the effects of this infusion on extracellular $\mathrm{ACh}$ in hippocampus were recorded with a second microdialysis probe [7]. Intraseptal administration of thioperamide increased significantly the spontaneous release of $\mathrm{ACh}$ from hippocampus of freely moving rats by up to about $100 \%$ [7]. Cimetidine, an $\mathrm{H}_{2}$ receptor antagonist [38], fully antagonized the effect of thioperamide. Also cimetidine was administered locally into the septum [7]. Thus, assuming that intraseptal administration of thioperamide produced an increase of endogenous histamine extracellular levels, this study further supports the suggestion that histaminergic neurons projecting to the septum [96] facilitate hippocampal cholinergic activity. The blockade of thioperamide effect on hippocampal ACh release by cimetidine suggests that endogenous histamine interacted with postsynaptic $\mathrm{H}_{2}$ receptors, although it is not yet clear whether $\mathrm{H}_{2}$ receptors are located on the septal cholinergic cell bodies, or on hypothetical neurons, which in turn facilitate the release of hippocampal ACh. Also intraseptal administration of ciproxifan, another $\mathrm{H}_{3}$ receptor antagonist [75], increased ACh spontaneous release from hippocampus of freely moving rats by about $100 \%$, and its effect was fully antagonized by cimetidine [6], thus confirming the hypothesis that histaminergic efferents to the septum facilitate hippocampal cholinergic activity through $\mathrm{H}_{2}$ receptor activation.

Electrophysiological findings indicated that histamine depolarized MSA-DB cholinergic neurons in a slice preparation of rat brain, producing an increase in sodium conductance which led these neurons to threshold for firing spontaneous action potentials [54]. The effect was attributed to $\mathrm{H}_{1}$ receptor activation, since it was significantly reduced by mepyramine (also known as pyrilamine) and promethazine [54], both $\mathrm{H}_{1}$ receptor antagonists [61]. However, the concentrations employed were very high, and the authors may have underestimated additional nonspecific properties of these two compounds [60]. Moreover, depolarization induced by histamine was transient, being desensitization within seconds, its prominent feature and the excitation diminished despite continued application of histamine [54]. If the effect on ACh release was very rapid, it is possible that it became obscured during the attainment of the 20-min perfusion sample, thus explaining why the biochemical studies mentioned above have failed to find an effect of $\mathrm{H}_{1}$ receptor blockade on septohippocampal cholinergic activity. In contrast to earlier cited microdialysis studies, Dringenberg and colleagues [36] demonstrated that systemic administration of mepyramine caused a very large increase of $\mathrm{ACh}$ spontaneous release from hippocampus of urethane- 
anesthetized rats, thus suggesting an implication also for $\mathrm{H}_{1}$ receptors. The discrepancy between this study and Mochizuki's work [83], which failed to show any effect of mepyramine, may be related to differences in the doses used, $10-20$ and $5 \mathrm{mg} / \mathrm{kg}$, respectively. Moreover, these $\mathrm{H}_{1}$ receptor antagonists possess marked antimuscarinic properties $[59,60]$, and consequently their selectivity between the three different histamine receptors [61] does not guarantee an unambiguous characterization.

\section{Modulation of $c$-fos expression by histamine}

In addition to the effect on hippocampal ACh release, $c$-fos immunoreactivity was detected in the medial septum 90 min after intraseptal administration of ciproxifan [6]. Significantly fewer $c$-fos immunoreactive nuclei were seen in control. Also the effect of ciproxifan on $c$-fos expression was fully antagonized by cimetidine [6]. Morphological features indicate that $c$-fos was expressed in neuronal cells, but the type of neuron has not been identified yet. The protoncogene $c$-fos is an immediate-early gene linked to genomic events in the cellular response to environmental signals [116], and has provided a useful marker for tracing the effects of pharmacological, electrical and physiological stimuli in the CNS [85]. Although increased hippocampal ACh release and $c$-fos expression might be dissociated processes, despite the identity of the stimulus, these observations may have implications for the treatment of disorders associated with impaired septo-hippocampal cholinergic functions.

\section{Modulation of cholinergic tone in the cortex and in the amygdala by histamine}

In addition to the findings indicating interactions between histamine and the septo-hippocampal cholinergic pathway, there is also evidence that histamine may have a regulatory role on the release of $\mathrm{ACh}$ also in the NBM-cortical and the NBM-amygdaloid pathways. Two different laboratories reported that histamine inhibited potassium-evoked release of $\left[{ }^{3} \mathrm{H}\right]$-ACh from rat cortical slices preloaded with $\left[{ }^{3} \mathrm{H}\right]$-choline through activation of $\mathrm{H}_{3}$ receptors $[3,23]$. The effects of histamine and agents acting at histamine receptors on spontaneous and potassium-evoked release of ACh were also investigated in vivo, using microdialysis to simultaneously administer histamine and monitor changes in endogenous ACh release from cortex of freely moving rats $[14,15]$. Histamine, administered locally into the cortex, failed to affect ACh spontaneous release. Conversely, it inhibited concentration-dependently potassium-elicited release of $\mathrm{ACh}$. The $\mathrm{H}_{3}$ receptor agonists
$\mathrm{R}$ - $\alpha$-methylhistamine, imetit $[46,62,126]$, and immepip [128] mimicked the effect of histamine, showing a slightly greater potency than histamine [14]. Oppositely, neither 2-thiazolylethylamine [45], an agonist showing some selectivity for $\mathrm{H}_{1}$ receptors, nor the $\mathrm{H}_{2}$ receptor agonist dimaprit [98] modified potassium-evoked release of ACh [14]. The inhibitory effect of $100 \mu \mathrm{M}$ histamine, a concentration producing the maximal effect [14], was completely prevented by histamine $\mathrm{H}_{3}$ receptor antagonists, such as clobenpropit [126] and thioperamide, but was resistant to antagonism by triprolidine [65] and cimetidine, antagonists at histamine $\mathrm{H}_{1}$ and $\mathrm{H}_{2}$ but not $\mathrm{H}_{3}$ receptors [14,15]. All agonists and antagonists were administered locally, dissolved into the perfusion medium. The concentration of potassium used in these studies, $100 \mathrm{mM}$, is only apparently high, for the low recovery of potassium through the microdialysis membrane [134], and the rapid dilution of potassium in the extracellular space necessitate high concentrations in the perfusion fluid. In fact, 60 $\mathrm{mM}$ potassium had only a slight effect on ACh release during brain dialysis [133], and perfusion of the cortex in vivo with $100 \mathrm{mM}$ potassium evoked an increase in ACh release $[14,15]$ similar to that obtained with incubation of cortical slices in $20 \mathrm{mM}$ potassium [23]. $\mathrm{H}_{3}$ receptor-induced inhibition of potassium-evoked release of ACh was completely abolished in cortices in which the traffic of action potentials was blocked by tetrodotoxin, a voltage-dependent sodium-channel blocker [14]. Thus, $\mathrm{H}_{3}$ receptors modulating $\mathrm{ACh}$ release are likely located neither presynaptically on cholinergic nerve terminals, nor on non-cholinergic nerve endings impinging on the former. They are most likely somatodendritic receptors on interneurons, the excitation of which produced sodium-dependent action potentials that release an intermediary modulatory substance. Consistently, in synaptosomes of entorhinal cortex, the release of $\left[{ }^{3} \mathrm{H}\right]-$ ACh remained unaltered in the presence of two $\mathrm{H}_{3}$ receptor agonists [3], thus strongly suggesting that $\mathrm{H}_{3}$ receptors modulating cortical ACh release are located postsynaptically on intrinsic perikarya [3]. Indeed, $\mathrm{H}_{3}$ receptors are not restricted to extrinsic histaminergic nerve endings [107], and $\mathrm{H}_{3}$ receptor-mediated inhibition of the release of neurotransmitters other than histamine has been described [113]. Moreover, lesion experiments demonstrated that $\mathrm{H}_{3}$ heteroreceptor number present on intrinsic neurons or other target cells is, at least in some regions, much greater than that of $\mathrm{H}_{3}$ autoreceptors [107]. Consistently, degeneration of perikarya by local infusion of kainate strongly decreased the number of $\mathrm{H}_{3}$ receptors in the striatum and the cerebral cortex $[26,107]$.

Recent microdialysis experiments demonstrated that bicuculline, a $\mathrm{GABA}_{\mathrm{A}}$ receptor antagonist, reversed the inhibition of ACh release induced by immepip, an $\mathrm{H}_{3}$ receptor agonist, thus suggesting a GABAergic involve- 
ment [48]. Furthermore, immepip, at a concentration that produced a maximal inhibition of potassiumevoked ACh release [14] increased $100 \mathrm{mM}$ potassiumevoked release of GABA from the cortex of freely moving rats by more than 50\% [48]. Thus it is conceivable that $\mathrm{H}_{3}$ receptors, localized postsynaptically on intrinsic perikarya, facilitated GABA release, which, in turn, inhibited ACh release. The most simple hypothesis is that GABA activated $\mathrm{GABA}_{\mathrm{A}}$ receptors localized on cholinergic nerve endings, thus reducing $\mathrm{ACh}$ release. Experimental evidence suggests that the cortical GABAergic system exerts a tonic inhibition of spontaneous release of ACh from the cortex, and that this inhibitory tone is maximal [49]. This could elucidate why neither histamine nor either of $\mathrm{H}_{3}$ receptor agonists altered spontaneous ACh release [14], much of which is tetrodotoxin sensitive [14]. Under resting conditions, since the inhibition of ACh release caused by GABA is maximal, $\mathrm{H}_{3}$ activation would have no effect on spontaneous $\mathrm{ACh}$ release. However, activation of $\mathrm{H}_{3}$ receptors, by increasing the release of GABA, will antagonize the potassium-induced depolarization, thus, depress, at least partially, potassium-evoked acetylcholine release. Alternatively, another synaptic arrangement consonant with the lack of $\mathrm{H}_{3}$ modulation of spontaneous release is that the activated interneurons inhibit the release of an excitatory presynaptic modulator of cholinergic terminals. If this excitatory pathway were not spontaneously active, $\mathrm{H}_{3}$ activation would have no effect on spontaneous ACh release. In the presence of potassium, this excitatory modulator would be released and enhance the depolarization-induced release of ACh. Activation of $\mathrm{H}_{3}$ receptors would remove this enhancement and partially, but not completely, depress potassium-evoked ACh release. Cortical GABA interneurons control the activity of large populations of principal cells through their extensive axon arborization [42]. Therefore, any pathway, even if relatively sparse such as the histaminergic pathway, may exert a powerful effect on the activity of the cortex if it modulates the activity of local GABA interneurons.

Histaminergic modulation of cortical cholinergic tone appears to be complex and multifaceted, and consists of two components, one inhibitory related to local actions at the terminals, the other excitatory resulting from interactions with cholinergic cell bodies in the NBM. Indeed, an electrophysiological study in guinea-pig basal forebrain slices, reporting that histamine depolarized NBM cholinergic mainly through $\mathrm{H}_{1}$ receptor activation [70], suggests that histaminergic neurons might also facilitate cortical cholinergic release. An intact, whole animal approach yielded important insight into the physiological role of histamine in modulating cortical cholinergic activity, rats were implanted with two microdyalisis probes; one in the NBM to deliver locally the different drugs; and the other in the cortex to measure the output of ACh [22]. The administration of histamine into the NBM increased concentration-dependent the output of ACh from the cortex of freely moving rats by about $100 \%$ [22]. ACh release elicited by $100 \mu \mathrm{M}$ histamine was insensitive to blockade of $\mathrm{H}_{2}$ and $\mathrm{H}_{3}$ receptors by means of cimetidine and thioperamide [22]. Conversely, triprolidine, an $\mathrm{H}_{1}$ receptor antagonist, reduced significantly the effect of $100 \mu \mathrm{M}$ histamine [22]. Although, mechanisms concomitant to $\mathrm{H}_{1}$ receptor activation cannot be excluded, both electrophysiological and biochemical findings indicate that histamine in the NBM facilitates the cortical cholinergic activity, and strongly suggest that $\mathrm{H}_{1}$ receptor activation is, at least in part, responsible for this effect. The dual effect of histamine on cortical cholinergic activity, excitatory at the level of NBM cell bodies, and inhibitory at the level of cholinergic terminals [14,48], may have implications for the treatment of disorders associated with impaired cortical cholinergic functions.

The amygdala is involved in the cognitive evaluation of the emotional content of complex cues, and acquisition of characteristic responses to aversive events depends on its integrity [122]. The basolateral nuclei, which receive major inputs from cortical and subcortical sensory areas [29], also receive cholinergic innervation from NBM [78] and histaminergic innervation from the hypothalamus [96]. Furthermore, autoradiographic and immunohistochemical studies have shown high densities of both $\mathrm{H}_{3}$ [107] and muscarinic receptors in this brain region [127]. Modulation of cholinergic transmission in the amygdala may be important for the acquisition or expression of relevant behaviors. Local administration of thioperamide decreased significantly the spontaneous release of ACh from basolateral nuclei of freely moving rats by about $50 \%$ [101]. This effect was fully blocked by cimetidine [101]. The inhibitory effect of thioperamide on ACh release may be explained by an interaction with $\mathrm{H}_{3}$ autoreceptors. Blockade of these receptors caused an increase of extracellular levels of endogenous histamine [5]. Therefore, this study suggests that activation of histaminergic neurons projecting to the amygdala basolateral nuclei inhibits the cholinergic tone in this area. Postsynaptic $\mathrm{H}_{2}$ receptors seem to mediate this effect, since pretreatment with cimetidine fully antagonized the effect of thioperamide. Whether $\mathrm{H}_{2}$ receptors are located on cholinergic terminals, or on hypothetical interneurons is not clear yet.

\section{Histamine and cognition}

Despite the complexity of the neuromodulatory relationship between cholinergic and histaminergic systems, a clear connection between histamine and learning and memory-related processes is provided by its involve- 
ment in the induction of long term potentiation (LTP) in area CA1 of rat hippocampal slices [19]. LTP has been suggested to be the physiological correlate of memory formation [17]. Histamine-induced modulation of synaptic plasticity is not consequent to activation of classical histamine $\mathrm{H}_{1}, \mathrm{H}_{2}$ or $\mathrm{H}_{3}$ receptors [19], but it is attributable to an interaction with the polyamine-binding sites on the NMDA receptor complex [12,129]. However, behavioral studies on animal models have provided extensive experimental evidence that the classical histamine receptors are also involved in histamine effects on learning and memory. For example, immediate post-training administration of histamine facilitated retention of a step-down inhibitory avoidance behavior, and this effect was antagonized by the simultaneous administration of both prometazine, an $\mathrm{H}_{1}$ receptor antagonist, and cimetidine, an $\mathrm{H}_{2}$ receptor antagonist [30,31]. Consistently, histamine improved the response latency in a one-way active avoidance response of aged rats [124]. This effect was mimicked by $\mathrm{H}_{1}$ receptor agonists, and antagonized by $\mathrm{H}_{1}$ receptor antagonists [124]. Aged animals are impaired in the acquisition of several learning procedures, such as both active and passive avoidance or maze learning [124]. Central histamine receptors are implicated also by findings that oral administration of classical $\mathrm{H}_{1}$ receptor antagonists, such as mepyramine and promethazine retarded the acquisition and impaired the retention of acquired learning in an active avoidance task, while $\mathrm{H}_{1}$ receptor antagonists less liable to cross the blood brain barrier, such as astemizole and oxatomide, caused only a weak depression of the avoidance response [66]. Interestingly, histamine as well as acetylcholine antagonized the effects of mepyramine [68], thus indicating that histaminergic and cholinergic central systems might exert a functional interaction in this behavior. In fact, although mepyramine's antimuscarinic properties are well known, it seems unlikely that they accounted for this effect, since the dose of acetylcholine required for preventing mepyramine-elicited amnesia was clearly very high, ten times higher than that able to antagonize the inhibitory effect of atropine [68]. In these studies histamine was always administered intracerebroventricularly, since this amine doesn't cross the blood-brain barrier [55]. It is, however, dubious whether or not injection of histamine truly reflects the actions of endogenous histamine in the brain. A possible answer to this question arises from investigations on the effects of L-histidine. In fact, histamine in brain is formed from L-histidine, which is taken up by an active process, and decarboxylated by a specific L-histidine decarboxylase (EC 4.1.1.22), which is not saturated under normal conditions [56]. Therefore, administration of L-histidine raised brain histamine levels [115]. Administration of L-histidine to hippocampus-lesioned rats amply increased hippocampal histamine content, and reduced significantly the lesion-induced deficits of both acquisition and retention of an active avoidance response [124]. L-Histidine also ameliorated learning deficits induced by scopolamine in mice exposed to an elevated plus-maze test [79], and was effective in improving rat learning performances in the olfactory social memory test [108], which is based on the investigation time of a juvenile rat by an adult rat, and measures a form of short-term memory [125]. These improvements of learning behaviors were mediated by newly synthesized brain histamine, since they were prevented by pretreatment with $\alpha$-fluoromethylhistidine [79,124], although peripherally administered histamine was ineffective [79]. Mepyramine antagonized L-histidine ameliorating effects, thus confirming a role of central $\mathrm{H}_{1}$ receptors [79]. The blockade of L-histidine decarboxylase by $\alpha$ fluoromethylhistidine lowered histamine content in those cells, such as histaminergic neurons, where the amine turned over rapidly [132]. Administration of $\alpha$-fluoromethylhistidine produced a significant suppression of memory retrieval and learning acquisition of active avoidance response [67,124]. Interestingly, the duration of the response latency was highly correlated with the depletion of histamine content in specific brain areas, such as hippocampus and hypothalamus [67,124]. It is important to remark that effective doses of $\alpha$ fluoromethylhistidine failed to influence locomotor activity [67,93], thus supporting the hypothesis that the decrease of neuronal histamine was directly responsible for cognitive impairments. In contrast to the hypothesis that histamine improves cognitive function, other studies implicate a negative role of histamine on learning and memory processes. Rats treated with $\alpha$ fluoromethylhistidine showed increased learning abilities in a maze paradigm, where they had to learn to avoid a foot shock [20]. Moreover, localized histamine injections into rat hippocampus prolonged significantly the latency time to escape in an active avoidance response [2]. Recently, the effects of lesions of the tuberomammillary nucleus on the performance of adult and aged rats in a set of cognitive tasks have been reported; in addition to a marked decrease in the number of histaminergic neurons, these lesions produced an improvement in every cognition test applied, and strongly diminished the age-related learning deficits [43]. Since amplification of the reward after hypothalamic stimulation was demonstrated following bilateral lesions of the tuberomammillary nucleus [63], one might suggest that tuberomammillary nucleus lesions facilitated cognition by enhancing the function of the reinforcement system. Interestingly, the implication of these studies, that the histaminergic system might exert an inhibitory tone on cognitive processes, could be readily integrated with findings that brain histaminergic activity was higher in the elderly $[109,110]$, and histamine content of rat brain increased with age [92]. In conclusion, a role of his- 
Table 1

Effects of $\mathrm{H}_{3}$ receptor antagonists on cognitive tasks

\begin{tabular}{llll}
\hline Drug & Behavior test & Effect & Reference \\
\hline Ciproxifan & Five-choice & Improvement & {$[75]$} \\
Clobenpropit & $\begin{array}{l}\text { Passive } \\
\text { avoidance } \\
\text { Object }\end{array}$ & Improvement & {$[51]$} \\
& $\begin{array}{l}\text { Improvement } \\
\text { recognition }\end{array}$ & {$[51]$} \\
FUB 181 & $\begin{array}{l}\text { Elevated } \\
\text { plus-maze }\end{array}$ & Improvement & {$[91]$} \\
Thioperamide & $\begin{array}{l}\text { Social memory } \\
\text { test }\end{array}$ & Improvement & {$[108]$} \\
& $\begin{array}{l}\text { Passive } \\
\text { avoidance }\end{array}$ & Improvement & {$[51,77]$} \\
& $\begin{array}{l}\text { Object } \\
\text { recognition }\end{array}$ & Improvement & {$[51]$} \\
& & &
\end{tabular}

tamine in learning and memory processes is highly probable, but at present experimental evidence appears to be inadequate to enable firm conclusions to be drawn on this role. The knowledge of the distinct and possibly opposing modulatory actions that histaminergic tuberomammillary neurons might exert by activating different receptor subtypes on specific neuronal networks involved in different learning processes may help resolve the controversy concerning its role in cognition.

Promising data have been obtained with $\mathrm{H}_{3}$ receptor antagonists, which have been found to improve the performance of rodents in various cognitive tests (Table 1). Indeed, thioperamide, an $\mathrm{H}_{3}$ receptor antagonist, improved rat performance in the olfactory, social memory test [108]. In rats, ciproxifan enhanced attention as evaluated in the five-choice task performed using a short stimulus duration [75]. Ciproxifan is a potent and selective $\mathrm{H}_{3}$ receptor antagonist, which, being orally bioavailable, appears promising for therapeutic applications in aging disorders. Other studies, however, reported that the procognitive effects of $\mathrm{H}_{3}$ receptor antagonists became fully evident only when behavioral deficits were pronounced. For example, while thioperamide improved significantly, the response latency in a passive avoidance response in senescence-accelerated mice (these animals showed a marked age-accelerated deterioration in learning tasks of passive avoidance), it was ineffective in normal-rate aging mice [77]. Consistently, two $\mathrm{H}_{3}$ receptor antagonists, thioperamide and clobenpropit [126], lacked any procognitive effect in control animals [51], but fully reverted rats cognitive impairments, measured in a passive avoidance response and object recognition, caused by injection of scopolamine $(0.2 \mathrm{mg} / \mathrm{kg}$, i.p. $)$ [51]. Similarly, FUB 181, another $\mathrm{H}_{3}$ receptor antagonist [119], significantly ameliorated performances of scopolamine-impaired mice $(0.5 \mathrm{mg} / \mathrm{kg}$, i.p. $)$ in the elevated plus-maze test [91]. Other studies, however, reported that administration of thioperamide or clobenpropit to scopolamine-impaired mice $(1 \mathrm{mg} / \mathrm{kg}$, i.p.) only attenuated scopolamine-induced impairments in the elevated plus-maze test and the step-through passive avoidance test, [80-82]. The use of a higher dose of scopolamine might explain this discrepancy.

Object recognition and passive avoidance responses might involve cholinergic neurons of the NBM, since both tasks were impaired by the cholinergic antagonist scopolamine [40,118]. In addition, axon-sparing ibotenic acid bilateral lesions of NBM neurons, including the cholinergic ones, which provide the innervation to the cortex and to the amygdala $[39,78]$, disrupted the performance of rats in both tasks $[9,37,95,106]$. In fact, these paradigms serve to measure a form of episodic memory, possibly localized in the frontal cortex [53] and the amygdala [95]. Cognitive improvements produced by administration of $\mathrm{H}_{3}$ receptor antagonists might be the result of relieving the inhibitory action on cortical acetylcholine by local $\mathrm{H}_{3}$ receptors (see Section 4). A second potential mechanism that may have contributed to the effects of $\mathrm{H}_{3}$ antagonists is the modulation of endogenous histamine release. Endogenous histamine exerted a tonic influence on cholinergic neurotransmission, enhancing cholinergic activity at the level of cholinergic cell bodies in the basal forebrain $[7,22,83]$. Thus, $\mathrm{H}_{3}$ receptor antagonists, by increasing the release of endogenous histamine, may facilitate cholinergic activity in brain areas crucial for cognitive functions. However, a beneficial effect on a scopolamine-induced deficit is a concomitant observation, but does not prove in anyway that cholinergic neurons are involved. Reversal of impairments observed in the above mentioned studies may be also due to histamine direct effects on cognition, and/or to histaminergic modulation of any number of transmitter systems. More persuasive evidence of a close relationship between the cholinergic and histaminergic system in learning and memory is offered by the results of experiments with $\mathrm{H}_{3}$ receptor agonists. Rat systemic pre-training administration of imetit and $\mathrm{R}-\alpha$-methylhistamine moderated potassium-evoked release of cortical ACh and impaired performance in object recognition and a passive avoidance response [14]. The disruption of the cortical cholinergic system may account for the cognitive impairments, since reduced availability of $\mathrm{ACh}$ in the synaptic cleft appeared related to cognitive deficits [111]. The lack of effectiveness of the same doses of imetit and $\mathrm{R}$ - $\alpha$-methylhistamine when administered post-training, suggests that the $\mathrm{H}_{3}$ receptor is involved in the acquisition but not the recall of this information [51]. However, ACh may control both acquisition and retention processes, since also post-training administration of scopolamine resulted in animals exhibiting significantly shorter escape latencies during a passive avoidance response, and spending similar amount of 
time exploring new and familiar objects [51]. Therefore, the impairment of cognition by $\mathrm{H}_{3}$ receptor agonists is unlikely attributable solely to the modulation of cortical acetylcholine. One might envisage mechanisms other than the cholinergic one, and the finding that $\mathrm{R}-\alpha-$ methylhistamine improved rodent spatial learning and memory, assessed using a water maze [117], supports this contention. Spatial learning is a primary function of the rodent hippocampus [90], and the water maze test is exquisitely sensitive to hippocampal lesions [87], but $\mathrm{H}_{3}$ receptor stimulation is expected to decrease hippocampal cholinergic activity [6,7].

\section{Conclusions}

For the complexity of the neuronal networks in the brain, it seems naïve to assume that only one neurotransmitter, namely $\mathrm{ACh}$, regulates such a complex mechanism as learning and memory. Other neurotransmitter systems have been implicated in these processes. Decker and McGaugh [33] suggested a model in which, although ACh has a central role, interactions with other neurotransmitters, such as dopamine, GABA, noradrenaline, are essential for the formation of memory. This hypothesis is supported by several studies $[18,52,112,121]$. However, the modulation of the cholinergic pathways by other neurotransmitter systems, and the importance of the cholinergic system as a final effector in learning and memory, still needs to be defined. The aim of this review is to critically assess biochemical, electrophysiological and behavioral evidence of interactions between the cholinergic and the histaminergic systems, and to examine the possible role of such interactions in learning and memory. Biochemical as well as electrophysiological evidence indicates that $\mathrm{ACh} /$ histamine interactions appear to be complex and multifaceted (Fig. 1). Histamine activates cortical $\mathrm{H}_{3}$ receptors, which are likely localized on GABA interneurons, and inhibits the release of cortical ACh through a GABAergic mechanism $[14,48,50]$. On the other hand, histaminergic projections to NBM exert a tonic influence on cortical cholinergic activity, depolarizing cholinergic cell bodies through activation of $\mathrm{H}_{1}$ receptors $[22,70]$, thus increasing $\mathrm{ACh}$ release from the cortex [22]. Conversely, activation of histaminergic neurons projecting to the basolateral nuclei of the amygdala inhibits the cholinergic tone in this area, and postsynaptic $\mathrm{H}_{2}$ receptors seem responsible for this effect [101]. Finally, histamine effects on hippocampal cholinergic activity may involve actions at different anatomical locations. Local administration of histamine failed to affect ACh release from hippocampus, but MSA-DB endogenous histamine facilitates hippocampal cholinergic activity through activation of postsynaptic $\mathrm{H}_{2}$ receptors possibly localized on septal cholinergic perikarya $[6,7,83]$. It is obvious that any attempt to strictly correlate physiological data with the outcome of behavioral tests is destined to fail. In several circumstances, though, one may envisage possible scenarios to account for the memory improving or impairing effects of histaminergic compounds in terms of modifications of $\mathrm{ACh}$ release. As an example, the depressant effect of $\mathrm{H}_{1}$ antagonists on active avoidance response seems consistent with the action of $\mathrm{H}_{1}$ receptors on NBM cholinergic neurons. A potential mechanism that may contribute to procognitive effects of $\mathrm{H}_{3}$ antagonists is the modulation of endogenous histamine release, which is under an inhibitory feedback control by $\mathrm{H}_{3}$ autoreceptors [5,84]. Endogenous histamine exerts a tonic influence on cholinergic neurotransmission, enhancing cholinergic activity at the level of cholinergic cell bodies in the NBM and MSA-DB [7,22,83]. Thus $\mathrm{H}_{3}$ receptor antagonists, by increasing the release of endogenous histamine, may facilitate cholinergic activity in brain areas crucial for cognitive functions. It should be kept in mind, though, that the systemic administration of these histaminergic compounds can not account for a selective action on restricted brain regions. The scenario is certainly more complex; indeed, $\mathrm{R}$ - $\alpha$-methylhistamine-induced improvement of rat performance in a water maze test [117] calls for a different explanation than simple $\mathrm{ACh} /$ histamine interactions. $\mathrm{R}-\alpha$-methylhistamine modulates, in addition to $\mathrm{ACh}$, the release of either 5-HT or noradrenaline [114], and each of these transmitters has been shown to alter performance in a variety of cognitive tests [33]. Therefore, the possibility that at least some cognitive effects of histamine and histaminergic agents occur independently of ACh, cannot be excluded. It is also important to note that cognitive tasks don't necessarily imply that all behavioral changes should be interpreted in terms of learning and memory, since the link between the behavioral change and a cognitive process is not a one-to-one relationship. For instance, in a water maze test, escape latency may reflect not only the ability to learn the position of the hidden platform, but also exploratory aspects of the behavior.

While our understanding of the histaminergic system and its role in learning and memory is far from complete, we have progressed to the point where it is possible to address the importance of treatment strategies that, taking advantage of non-cholinergic drugs that potentiate cholinergic functions, may produce beneficial effects on disorders associated with impaired cholinergic functions, such as Alzheimer's disease [24]. This indirect approach appears preferable over cholinomimetic strategies. In fact, cholinergic drugs used in most clinical trials have resulted in greater stimulation of inhibitory autoreceptors either by increasing the half-life of acetylcholine in the synaptic cleft [28] or by directly activating these receptors due to the poor selec- 
tivity of the agonists available [47]. Indirect stimulation of residual cholinergic neurons may be achieved with appropriate pharmacological intervention. Thus, $\mathrm{H}_{3}$ receptor antagonists could correct the deficits resulting from cholinergic hypofunction, and provide a novel approach to improve cognitive deficits.

\section{Acknowledgements}

This work was supported by grants $40 \%$ (M.U.R.S.T) and 60\% (M.U.R.S.T.-Universitá di Firenze, Italy).

\section{References}

[1] Airaksinen M, Paetau A, Paljärvi L, Reinikainen K, Riekkinen P, Suomalainen R, Panula P. Histamine neurons in human hypothalamus: anatomy in normal and Alzheimer diseased brain. Neuroscience 1991;44:465-81.

[2] Alvarez EO, Banzan AM. Effects of localized microinjections into the hippocampal formation on the retrieval of a one-way active avoidance response in rats. J Neural Transm (Gen Sect) 1995;101:201-11.

[3] Arrang JM, Drutel G, Schwartz JC. Characterization of histamine $\mathrm{H}_{3}$ receptors regulating acetylcholine release in rat enthorinal cortex. Br J Pharmacol 1995;114:1518-22.

[4] Arrang JM, Garbarg M, Lancelot JC, Lecont JM, Pollard H, Robba M, Schunack W, Schwartz JC. Highly-potent and selective ligands for histamine- $\mathrm{H}_{3}$ receptors. Nature 1987;327:11723.

[5] Arrang JM, Garbarg M, Schwartz JC. Auto-inhibition of brain histamine release mediated by a novel class $\left(\mathrm{H}_{3}\right)$ of histamine receptor. Nature 1983;302:832-7.

[6] Bacciottini L, Giovannelli L, Passani B, Schunack W, Mannaioni P, Blandina P. Ciproxifan and cimetidine modulate $c$-fos expression in septal neurons, and acetylcholine release from hippocampus of freely moving rats. Inflamm Res 2000;49:S412.

[7] Bacciottini L, Mannaioni P, Chiappetta M, Giovannini M, Blandina P. Acetylcholine release from hippocampus of freely moving rats is modulated by thioperamide and cimetidine. Inflamm Res 1999;48:S63-4.

[8] Bacciottini L, Mannaioni PF, Chiappetta M, Giovannini MG, Blandina $\mathrm{P}$. In vivo release of $\mathrm{ACh}$ from hippocampus is modulated by histaminergic afferents to the septum. In : XVIIth Annual Meeting of the European Histamine Research Society. 1998. Lodz (PL), 20-23 May.

[9] Bartolini L, Casamenti F, Pepeu G. Aniracetam restores object recognition impaired by age, scopolamine, and nucleus basalis lesions. Pharmacol Biochem Behav 1996;53:277-83.

[10] Bartus RT, Dean RL, Beer B, Lippa AS. The cholinergic hypothesis of geriatric memory dysfunction. Science 1982;217:408-17.

[11] Bassareo V, DiChiara G. Differential influence of associative and nonassociative learning mechanisms on the responsiveness of prefrontal and accumbal dopamine transmission to food stimuli in rats fed ad libitum. J Neurosci 1997;17:851-61.

[12] Bekkers JM. Enhancement by histamine of NMDA-mediated synaptic transmission in the hippocampus. Science 1993;261:104-6.
[13] Blandina P, Bacciottini L, Giovannini MG, Mannaioni PF. $\mathrm{H}_{3}$ modulation of the release of neurotransmitters in vivo. In: Leurs R, Timmerman H, editors. The Histamine $\mathrm{H}_{3}$ Receptor a Target for New Drugs, vol. 30. Amsterdam: Elsevier, 1998:2740.

[14] Blandina P, Giorgetti M, Bartolini L, Cecchi M, Timmerman H, Leurs R, Pepeu G, Giovannini MG. Inhibition of cortical acetylcholine release and cognitive performance by histamine $\mathrm{H}_{3}$ receptor activation in rats. Br J Pharmacol 1996;119:165664.

[15] Blandina P, Giorgetti M, Cecchi M, Leurs R, Timmerman H, Giovannini MG. Histamine $\mathrm{H}_{3}$ receptor inhibition of $\mathrm{K}^{+}$evoked release of acetylcholine from rat cortex in vivo. Inflamm Res 1996;45:S54-5.

[16] Blandina P, Knott P, Leung LKH, Green JP. Stimulation of the histamine $\mathrm{H}_{2}$ receptor in the rat hypothalamus releases endogenous norepinephrine. $\mathbf{J}$ Pharmacol Exp Ther 1989;249:44-51.

[17] Bliss TVP, Collingridge GL. A synaptic model of memory: long term potentiation in the hippocampus. Nature 1993;361:31-9.

[18] Blokland A. Acetylcholine: a neurotransmitter for learning and memory. Brain Res Rev 1996;21:285-300.

[19] Brown RE, Fedorov NB, Haas HL, Reymann KG. Histaminergic modulation of synaptic plasticity in area CA1 of rat hippocampal slices. Neuropharmacology 1995;34:181-90.

[20] Cacabelos R, Alvarez XA. Histidine decarboxylase inhibition induced by $\alpha$-fluoromethylhistidine provokes learning-related hypokinetic activity. Agents Actions 1991;33:131-4.

[21] Calcutt RC, Ganellin CR, Griffiths R, Leigh BK, Maguire JP, Mitchell RC, Mylec ME, Parson ME, Smith IR, Young RC. Zolantidine (SK\&F95282) is a potent selective brain-penetrating histamine $\mathrm{H}_{2}$ receptor antagonist. $\mathrm{Br} \quad \mathrm{J}$ Pharmacol 1988;93:69-78.

[22] Cecchi M, Giorgetti M, Bacciottini L, Giovannini MG, Blandina P. Increase of acetylcholine release from rat cortex of freely moving rats by administration of histamine into nucleus basalis magnocellularis. Inflamm Res 1998;47:S32-3.

[23] Clapham J, Kilpatrick GJ. Histamine $\mathrm{H}_{3}$ receptors modulate the release of $\left[{ }^{3} \mathrm{H}\right]$-acetylcholine from slices of rat enthorinal cortex: evidence for the possible existence of $\mathrm{H}_{3}$ receptor subtypes. Br J Pharmacol 1992;107:919-23.

[24] Cohen BM, Renshaw PF, Stoll AL, Wurtman RJ, YurgelunTodd D, Babb SM. Decreased brain choline uptake in older adults-an in vivo proton magnetic resonance spectroscopy study. J Am Med Assoc 1995;274:902-7.

[25] Coyle J, Donald L, Delong M. Alzheimer's disease: a disorder of cortical cholinergic innervation. Science 1983;219:1184-6.

[26] Cumming P, Shaw C, Vincent SR. High affinity histamine binding site is the $\mathrm{H}_{3}$ receptor: characterization and autoradiographic localization in rat brain. Synapse 1991;8:144-51.

[27] Davies P, Maloney A. Selective loss of central cholinergic neurons in Alzheimer's disease. Lancet 1976;2:1403-5.

[28] The Tacrine Collaborative Study Group, Davis K, Thai L, Gamzu E, Davis C, Woolson R, Gracon S, Drachman D, Schneider L, Whitehouse P, Hoover T, Morris J, Kawas C, Knopman D, Earl N, Kumar V, Doody R. A double-blind placebo-controlled multicenter study of tacrine for Alzheimer's disease. New Engl J Med 1992;327:1253-9.

[29] Davis M, Rainnie D, Cassel M. Neurotransmission in the rat amygdala related to fear and anxiety. Trends Neurosci 1994;17:208-14.

[30] De Almeida M, Izquierdo I. Memory facilitation by histamine. Arch Int Pharmacodyn Ther 1986;283:193-8.

[31] De Almeida M, Izquierdo I. Intracerebroventricular histamine, but not $48 / 80$, causes posttraining memory facilitation in the rat. Arch Int Pharmacodyn Ther 1988;291:202-7. 
[32] Decker MW. The effects of aging and cortical projections of the forebrain cholinergic system. Brain Res Rev 1987;12:423-8.

[33] Decker MW, McGaugh JL. The role of interactions between the cholinergic system and other neuromodulatory systems in learning and memory. Synapse 1991;7:151-68.

[34] Donoso AO. Induction of prolactin and luteinizing hormone release by histamine in male and female rats and the influence of brain transmitter antagonists. J Endocr 1978;76:193-202.

[35] Drachman DA. Memory and cognitive function in man: does the cholinergic system have a specific role? Neurology 1977;27:783-90.

[36] Dringenberg HC, DeSouza-Silva MA, Rossmüller J, Huston JP, Schwarting RKW. Histamine $\mathrm{H}_{1}$ receptor antagonists produce increases in extracellular acetylcholine in rat frontal cortex and hippocampus. J Neurochem 1998;70:1750-8.

[37] Dunnett SB, Whishaw IQ, Jones GH, Bunch ST. Behavioural, biochemical and histochemical effects of different neurotoxic amino acids into nucleus basalis magnocellularis of rats. Neuroscience 1987;20:653-69.

[38] Durant GJ, Emmett JC, Ganellin CR. Cyanoguanidinethiourea equivalence in the development of the histamine $\mathrm{H}_{2}$ receptor antagonist, cimetidine. J Med Chem 1977;20:901-6.

[39] Eckenstein FP, Baughman RW, Quinn J. An anatomical study of cholinergic innervation in rat cerebral cortex. Neuroscience 1988;25:457-74.

[40] Ennaceur A, Meliani K. Effects of physostigmine and scopolamine on rats' performances in object-recognition and radialmaze tests. Psychopharmacology 1992;109:321-30.

[41] Everitt BJ, Robbins TW. Central cholinergic systems and cognition. Annu Rev Psychol 1997;48:649-84.

[42] Freund TF, Meskenaite V. $\gamma$-Aminobutyric acid-containing basal forebrain neurons innervate inhibitory interneurons in the neocortex. Proc Natl Acad Sci USA 1992;89:738-42.

[43] Frisch C, Hasenöhrl RU, Haas HL, Weiler HT, Steinbusch HWM, Huston J. Facilitation of learning after lesions of the tuberomammillary nucleus region in adult and aged rats. Exp Brain Res 1998;118:447-56.

[44] Gallagher M, Colombo PJ. Aging the cholinergic hypothesis of cognitive decline. Curr Opin Neurobiol 1995;5:161-8.

[45] Ganellin CR. Chemistry and structure-activity relationships of drug acting at histamine receptors. In: Ganellin C, Parson ME, editors. Pharmacology of Histamine Receptors. Bristol, England: Wright, 1982:10-102.

[46] Garbarg M, Arrang J-M, Rouleau A, Ligneau X, Dam-TrungTuong M, Schwartz J-C, Ganellin CR. S-[2-(4-imidazolyl)ethyl]isothiourea, a highly specific and potent histamine $\mathrm{H}_{3}$ receptor agonist. J Pharmacol Exp Ther 1992;263:304-10.

[47] Gauthier S, Gauthier L, Brochard R, Quirion R, Sultan S. Treatment of Alzheimer's disease: hopes and reality. Can J Neurol Sci 1991;18:439-41.

[48] Giorgetti M, Bacciottini L, Bianchi L, Giovannini MG, Cecchi M, Blandina P. GABAergic mechanism in histamine $\mathrm{H}_{3}$ receptor inhibition of $\mathrm{K}^{+}$-evoked release of acetylcholine from rat cortex in vivo. Inflamm Res 1997;46:S3-4.

[49] Giorgetti M, Bacciottini L, Giovannini MG, Colivicchi MA, Goldfarb J, Blandina P. Local GABAergic modulation of acetylcholine release from the cortex of freely moving rats. Eur J Neurosci 2000;12:1941-8.

[50] Giorgetti M, Bacciottini L, Giovannini MG, Colivicchi L, Bianchi L, Blandina P. Characterization of histamine $\mathrm{H}_{3}$ receptors regulating acetylcholine release from cortex of freely moving rats. In: González-Mora JL, Borges R, Mas M, editors. Monitoring Molecules in Neuroscience. Tenerife: University of La Laguna, 1996:158-9.

[51] Giovannini MG, Bartolini L, Bacciottini L, Greco L, Blandina P. Effects of histamine $\mathrm{H}_{3}$ receptor agonists and antagonists on cognitive performance and scopolamine-induced amnesia. Behav Brain Res 1999;104:147-55.
[52] Giovannini MG, Ceccarelli I, Molinari B, Cecchi M, Godfarb J, Blandina P. Serotonergic modulation of acetylcholine release from cortex of freely moving rats. J Pharmacol Exp Ther 1998;285:1219-25.

[53] Goldman-Rakic PS. Circuitry of primate prefrontal cortex and regulation of behavior by representational memory. In: Plum F, editor. Handboock of Physiology, vol. 5. Bethesda, USA: American Physiol Soc, 1987:55-78.

[54] Gorelova N, Reiner PB. Histamine depolarizes cholinergic septal neurons. J Neurophysiol 1996;75:707-14.

[55] Green JP, Khandelwal JK. Histamine turnover in regions of rat brain. Adv Biosci 1985;51:185-94.

[56] Green JP, Prell GD, Khandelwal JK, Blandina P. Aspects of histamine metabolism. Agents Actions 1987;22:1-15.

[57] Hardy J, Adolfsson R, Alafuzoff I, Bucht G, Marcusson J, Nyberg P, Perdahl E, Wester P, Winblad B. Transmitter deficits in Alzheimer's disease. Neurochem Int 1985;7:545-63.

[58] Haroutunian V, Santucci AC, Davis KL. Implications of multiple transmitter system lesions for cholinomimetic therapy in Alzheimer's disease. In: Aquilonius SM, Gillberg PG, editors. Progress in Brain Research, vol. 84. Amsterdam: Elsevier, 1990:333-46.

[59] Hill SJ. Histamine receptors in the mammalian central nervous system: biochemical studies. In: Ellis GP, West GB, editors. Progress in Medicinal Chemistry, vol. 24. Amsterdam: Elsevier, 1987:29-84.

[60] Hill SJ. Distribution, properties, and functional characteristics of three classes of histamine receptor. Pharmacol Rev 1990;42:45-83.

[61] Hill SJ, Ganellin CR, Timmerman H, Schwartz JC, Shankley NP, Young JM, Schunack W, Levi R, Haas HL. International union of Pharmacology. XIII. Classification of histamine receptors. Pharmacol Rev 1997;49:253-78.

[62] Howson W, Parson ME, Raval P, Swayne GTG. Two novel, potent and selective histamine $\mathrm{H}_{3}$ receptor agonists. Bioorg Med Chem Lett 1992;2:77-8.

[63] Huston JP, Wagner U, Hasenöhrl RU. The tuberomammillary nucleus projections in the control of learning, memory and reinforcement processes: evidence for an inhibitory role. Behav Brain Res 1997;83:97-105.

[64] Inagaki N, Yamatodani A, Ando-Yamamoto M, Tohyama M, Watanabe T, Wada H. Organization of histaminergic fibers in the rat brain. J Comp Neurol 1988;273:283-300.

[65] Ison RR, Casy AF. Structural influence upon antihistamine activity: 3-amino-1-aryl-1-(2-pyridyl)-propenes and related compounds. J Pharm Pharmacol 1971;23:848-56.

[66] Kamei C. Influence of certain H1-blockers on the step-through active avoidance response in rats. Psychopharmacology 1990;102:312-8.

[67] Kamei C, Okumura Y, Tasaka K. Influence of histamine depletion on learning and memory recollection in rats. Psychopharmacology 1993;111:376-82.

[68] Kamei C, Tasaka K. Partecipation of histamine in the stepthrough active avoidance response and its inhibition by $\mathrm{H}_{1}$ blockers. Jpn J Pharmacol 1991;57:473-82.

[69] Kelly JS. Alzheimer's disease: the tacrine legacy. Trends Pharmacol Sci 1999;20:127-9.

[70] Khateb A, Fort P, Pegna A, Jones BE, Mühlethaler M. Cholinergic nucleus basalis neurons are excited by histamine in vitro. Neuroscience 1995;69:495-506.

[71] Kollonitsch J, Patchett AA, Marburg S, Maycock AL, Perkins LM, Doldouras GA, Duggan DE, Aster SD. Selective inhibitors of biosynthesis of aminergic neurotransmitters. Nature 1978;274:906-8.

[72] Kubanis P, Zornetzer SF. Age-related behavioral and neurobiological changes: a review with an emphasis on memory. Behav Neural Biol 1981;31:115-72. 
[73] Kuhl DE, Koeppe RA, Minoshima S, Snyder SE, Ficaro EP, Foster NL, Frey KA, Kilbourn MR. In vivo mapping of cerebral acetylcholinesterase activity in aging and Alzheimer's disease. Neurology 1999;52:691-9.

[74] LeMoal M, Simon H. Mesocortical dopaminergic network: functional and regulatory roles. Physiol Rev 1991;71:155-234.

[75] Ligneau X, Lin J-S, Vanni-Mercer G, Jouvet M, Muir JL, Ganellin CR, Stark H, Elz S, Schunack W, Schwartz J-C. Neurochemical and behavioral effects of ciproxifan, a potent histamine $\mathrm{H}_{3}$-receptor antagonist. J Pharmacol Exp Ther 1998;287:658-66.

[76] McEntee WJ, Crook TH. Serotonin, memory and the aging brain. Psychopharmacology 1991;103:143-9.

[77] Meguro K-I, Yanai K, Sakai N, Sakurai E, Maeyama K, Sasaki H, Watanabe T. Effects of thioperamide, a histamine H3 antagonist, on the step-through passive avoidance response and histidine decarboxylase activity in senescence-accelerated mice. Pharmacol Biochem Behav 1995;50:321-5.

[78] Mesulam MM, Mufson EJ, Wainer BH, Levey AI. Central cholinergic pathways in the rat: an overview based on an alternative nomenclature (Ch1-Ch6). Neuroscience 1983;10:1185-201.

[79] Miyazaki S, Imaizumi M, Onodera K. Ameliorating effects of histidine on scopolamine-induced learning deficits using an elevated plus-maze test in mice. Life Sci 1995;56:1563-70.

[80] Miyazaki S, Imaizumi M, Onodera K. Effects of thioperamide on the cholinergic system and the step-through passive avoidance test in mice. Methods Find Exp Clin Pharmacol $1995 ; 17: 653-8$.

[81] Miyazaki S, Imaizumi M, Onodera K. Effects of thioperamide, a histamine $\mathrm{H}_{3}$-receptor antagonist, on a scopolamine-induced learning deficit using an elevated plus-maze test in mice. Life Sci 1995;57:2137-44.

[82] Miyazaki S, Onodera K, Imaizumi M, Timmerman H. Effects of clobenpropit (VUF-9153), a histamine $\mathrm{H}_{3}$-receptor antagonist, on learning and memory, and on cholinergic and monoaminergic systems in mice. Life Sci 1997;61:355-61.

[83] Mochizuki T, Okakura-Mochizuki K, Horii A, Yamamoto Y, Yamatodani A. Histaminergic modulation of hippocampal acetylcholine release in vivo. J Neurochem 1994;62:2275-82.

[84] Mochizuki T, Yamatodani A, Okakura K, Takemura M, Inagaki $\mathrm{N}$, Wada $\mathrm{H}$. In vivo release of neuronal histamine in the hypothalamus of rats measured by microdialysis. NaunynSchmiedeberg's Arch Pharmacol 1991;343:190-5.

[85] Morgan JI, Curran T. Stimulus-transcription coupling in the nervous system: involvement of the inducible proto-oncogenes fos and jun. Annu Rev Neurosci 1991;14:421-51.

[86] Morisset S, traiffort E, Schwartz J-C. Inhibition of histamine versus acetylcholine metabolism as a mechanism of tacrine activity. Eur J Pharmacol 1996;315:R1-2.

[87] Morris RGM, Garrud P, Rawlins JNP, O'Keefe J. Place navigation impaired in rats with hippocampal lesions. Nature 1982;297:681-3.

[88] Murphy BL, Arnsten AF, Goldman-Rakic PS, Roth RH. Increased dopamine turnover in the prefrontal cortex impairs spatial working memory performance in rats and monkeys. Proc Natl Acad Sci USA 1996;93:1243-51.

[89] Nicoll RA. The septo-hippocampal projection: a model cholinergic pathway. Trends Neurosci 1985;8:533-6.

[90] O'Keefe J, Nadel L. The Hippocampus as a Cognitive Map. Oxford: Oxford Univ. Press, 1978.

[91] Onodera K, Miyazaki S, Imaizumi M, Stark H, Schunack W. Improvement by FUB 181, a novel histamine H3-receptor antagonist, of learning and memory in the elevated plus-maze test in mice. Naunyn Schmiedeberg's Arch Pharmacol 1998;357:508-13.
[92] Onodera K, Tuomisto L, Tacke U, Airaksinen M. Strain differences in regional brain histamine levels between genetically epilepsy-prone and resistant rats. Methods Find Exp Clin Pharmacol 1992;14:13-6.

[93] Onodera K, Yamatodani A, Watanabe T. Effects of $\alpha$ fluoromethylhistidine on locomotor activity, brain histamine and catecholamine contents in rats. Methods Find Exp Clin Pharmacol 1992;14:97-105.

[94] Onodera K, Yamatodani A, Watanabe T, Wada H. Neuropharmacology of the histaminergic neuron system in the brain and its relationship with behavioral disorders. Progr Neurobiol 1994;42:685-702.

[95] Page KJ, Everitt BJ, Robbins TW, Marston HM, Wilkinson LS. Dissociable effects on spatial maze and passive avoidance acquisition and retention following AMPA- and ibotenic acidinduced excitotoxic lesions of the basal forebrain in rats: differential dependence on cholinergic neuronal loss. Neuroscience 1991;43:457-72.

[96] Panula P, Pirvola U, Auvinen S, Airaksinen MN. Histamineimmunoreactive nerve fibers in the rat brain. Neuroscience 1989;28:585-610.

[97] Panula P, Yang HY, Costa E. Histamine-containing neurons in rat hypothalamus. Proc Natl Acad Sci USA 1984;81:2572-6.

[98] Parson ME, Owen DAA, Ganellin CR, Durant CJ. Dimaprit -[S-[3-( $N, N$-dimethyl-amino)propyl]isothiourea]- a highly specific histamine $\mathrm{H}_{2}$-receptor agonist: pharmacology. Agents Actions 1977;7:31-8.

[99] Passani M, Blandina P. Cognitive implications for $\mathrm{H}_{3}$ and 5- $\mathrm{HT}_{3}$ receptors modulation of cortical cholinergic function: a parallel story. Methods Find Exp Clin Pharmacol 1998;20:72533.

[100] Passani MB, Bacciottini L, Mannaioni PF, Blandina P. Central histaminergic system and cognitive processes. Neurosci Biobehav Rev 2000;24:107-13.

[101] Passani MB, Cangioli I, Bacciottini L, Mannaioni PF, Blandina P. Thioperamide and cimetidine modulate acetylcholine release from the amygdala of freely moving rats. Inflamm Res 2000;49:S43-4.

[102] Passani MB, Corradetti R. Therapeutic potentials of itasetron (DAU 6215), a novel 5- $\mathrm{HT}_{3}$ receptor antagonist, in the treatment of central nervous system disorders. CNS Drug Rev 1996;2:195-213.

[103] Perry E, Walker M, Grace J, Perry R. Acetylcholine in mind: a neurotransmitter correlate of consciousness? Trends Neurosci 1999;22:273-80.

[104] Perry EK, Perry RH, Blessed G, Tomlinson BE. Necropsy evidence of celebral cholinergic deficits in senile dementia. Lancet 1977;1:189.

[105] Perry EK, Tomlinson BE, Blessed G, Bergmann K, Gibson PH, Perry RH. Correlation of cholinergic abnormalities with senile plaques and mental test scores in senile dementia. Br Med $\mathbf{J}$ 1978;2:1457-9.

[106] Petrides M. Frontal lobes and behavior. Curr Opin Neurobiol 1994;4:207-11.

[107] Pollard H, Moreau J, Arrang JM, Schwartz J-C. A detailed autoradiographic mapping of histamine $\mathrm{H}_{3}$ receptors in rat brain areas. Neuroscience 1993;52:169-89.

[108] Prast H, Argyriou A, Philippu A. Histaminergic neurons facilitate social memory in rats. Brain Res 1996;734:316-8.

[109] Prell GD, Khandelwal JK, Burns RS, LeWitt PA, Green JP. Elevated levels of histamine metabolites in cerebrospinal fluid of aging, healthy humans. Compr Gerontol A 1988;2:114-9.

[110] Prell GD, Khandelwal JK, Burns RS, LeWitt PA, Green JP. Influence of age and gender on the levels of histamine metabolites and pros-methylimidazoleacetic acid in human cerebrospinal fluid. Arch Gerontol Geriatr 1991;12:1-12. 
[111] Quirion R, Wilson A, Rowe W, Aubert I, Richard J, Doods H, Parent A, White N, Meaney MJ. Facilitation of acetylcholine release and cognitive performance by an $\mathrm{M}_{2}$-muscarinic receptor antagonist in aged memory-impaired rats. J Neurosci 1995; 15:1455-62.

[112] Sarter M, Bruno JP, Dudchenko P. Activating the damaged basal forebrain cholinergic system: tonic stimulation versus signal amplification. Psychopharmacology 1990;101:1-17.

[113] Schlicker E, Kathmann M. Modulation of in vitro transmission in the CNS and in the retina via $\mathrm{H}_{3}$ heteroreceptors. In: Leurs $\mathrm{R}$, Timmerman $\mathrm{H}$, editors. The Histamine $\mathrm{H}_{3}$ Receptor a Target for New Drugs, vol. 30. Amsterdam: Elsevier, 1998:1326.

[114] Schlicker E, Malinowska B, Kathmann M, Gothert M. Modulation of neurotransmitter release via histamine $\mathrm{H}_{3}$ heteroreceptors. Fundam Clin Pharmacol 1994;8:127-8.

[115] Schwartz J-C, Lampart C, Rose C. Histamine formation in rat brain in vivo: effects of histidine loads. $\mathbf{J}$ Neurochem 1972;19:801-10.

[116] Sheng M, Greenberg ME. The regulation and function of $c$-fos and other immediate early genes in the nervous system. Neuron 1990;4:477-85.

[117] Smith CPS, Hunter AJ, Bennett GW. Effects of (R)- $\alpha$-methylhistamine and scopolamine on spatial learning in the rat assessed using a water maze. Psychopharmacology 1994;114:651-6.

[118] Spignoli G, Pepeu G. Interactions between oxiracetam, aniracetam and scopolamine on behavior and brain acetylcholine. Pharmacol Biochem Behav 1987;27:491-5.

[119] Stark H, Huls A, Ligneaux X, Purand K, Pertz H, Arrang JM, Schwartz JC, Schunack W. Development of FUB 181, a selective histamine $\mathrm{H}_{3}$-receptor antagonist of high oral in vivo potency with 4-(omega-(arylalkyloxy)alkyl)-1H-imidazole structure. Arch Pharm (Weinheim) 1998;331:211-8.

[120] Stark H, Scheich H. Dopaminergic and serotoninergic neurotransmission systems are differentially involved in auditory cortex learning: a long-term microdialysis study of metabolites. J Neurochem 1997;68:691-7.

[121] Steckler T, Shagal A. The role of serotonergic-cholinergic interactions in the mediatione of cognitive behavior. Behav Brain Res 1995;67:165-99.

[122] Swanson LW, Cowan WM. An autoradiographic study of the organization of the efferent connections of the hippocampal formation in the rat. J Comp Neurol 1977;172:49-84.

[123] Takeda N, Inagaki S, Taguchi Y, Tohyama M, Watanabe T, Wada $\mathrm{H}$. Origins of histamine-containing fibers in cerebral cortex of rats studied by immunohistochemistry with histidine decarboxylase as a marker and transection. Brain Res 1984;323:55-63.

[124] Tasaka K. The role of histamine on learning and memory. In: Tasaka K, editor. New Advances in Histamine Research. Tokyo: Springer, 1994:27-68.

[125] Thor DH, Holloway WR. Social memory of the male laboratory rat. J Comp Physiol Psychol 1982;96:1000-6.

[126] VanderGoot H, Schepers MJP, Sterk GJ, Timmerman H. Isothiourea analogues of histamine as potent agonists or antagonists of the histamine $\mathrm{H}_{3}$-receptor. Eur $\mathrm{J}$ Med Chem 1992;27:511-7.

[127] Van der Zee EA, Roozendaal B, Bohus B, Koolhaas JM, Luiten PGM. Muscarinic acetylcholine receptor immunoreactivity in the amygdala-I. Cellular distribution correlated with fear-induced behavior. Neuroscience 1997;76:63-73.

[128] Vollinga RC, deKoning JP, Jansen FP, Leurs R, Menge WMPB, Timmerman H. A new potent and selective histamine $\mathrm{H} 3$ receptor agonist, 4-(1H-imidazol-4-yl-methyl)piperidine (immepip). J Med Chem 1994;37:332-3.

[129] Vorobjev VS, Sharonova IN, Walsh IB, Haas HL. Histamine potentiates $N$-methyl-D-aspartate responses in acutely isolated hippocampal neurons. Neuron 1993;11:837-44.

[130] Wada H, Inagaki N, Yamatodani A, Watanabe $\mathrm{T}$. Is the histaminergic neuron system a regulatory center for wholebrain activity? Trends Neurosci 1991;14:415-8.

[131] Watanabe T, Taguchi Y, Shiosaka S, Tanaka J, Kubota H, Terano Y, Tohyama M, Wada H. Distribution of the histaminergic neuron system in the central nervous system of rats: a fluorescent immunohistochemical analysis with histidine decarboxylase as a marker. Brain Res 1984;295:13-25.

[132] Watanabe T, Yamatodani A, Maeyama K, Wada H. Pharmacology of $\alpha$-fluoromethylhistidine, a specific inhibitor of histidine decarboxilase. Trends Pharmacol Sci 1990;11:363-6.

[133] Westerink BHC, Damsa G, Rolema H, DeVries JB, Horn AS. Scope and limitations of in vivo brain dialysis: a comparison of its application to various neurotransmitter systems. Life Sci 1987;41:1763-76.

[134] Westerink BHC, deVries JB. A new method to estimate the migration rate of centrally acting drugs from microdialysis probes through brain tissues in conscious animals. In: Gonzáles-Mora JL, Borges R, Msa M, editors. Monitoring Molecules in Neuroscience. Tenerife: University of La Laguna, 1996:9-10.

[135] Woolf NJ, Eckenstein F, Butcher LL. Cholinergic systems in the rat brain. I. Projections to the limbic telencephalon. Brain Res Bull 1984;13:751-84. 